\title{
Further Evidence On The Ability Of FIFO And LIFO Earnings To Predict Operating Cash Flows: An Industry Specific Analysis
}

Brock Murdoch, California State University, Chico, USA

Bruce Dehning, Chapman University, USA

Paul Krause, California State University, Chico, USA

\begin{abstract}
The continuing convergence of U.S. GAAP with International Accounting Standards has brought into question the future use of the LIFO inventory method in the U.S. Since the Financial Accounting Standards Board (2010) has stipulated that earnings should aid investors and creditors in their quest to forecast future cash flows to the enterprise, this research examines whether FIFO earnings or LIFO earnings is preferable, for this purpose, as an aid to ex ante operating cash flow itself, over a three-year forecast horizon. We conclude that ex ante operating cash flows are quite useful in forecasting operating cash flows across industries for up to three years-ahead.
\end{abstract}

We find differing results with respect to the incremental predictive content of LIFO versus FIFO earnings, depending on industry and the forecast horizon. For the Manufacturing industry and the Services industry, LIFO earnings is superior to FIFO earnings for forecasting operating cash flows across the entire three year forecast horizon. In contrast, for the Retail Trade industry and the Finance, Insurance, and Real Estate industry, FIFO earnings is preferable for all three forecasts of operating cash flows.

For firms in the Transportation, Communications, Electric, Gas, and Sanitary Services industry and in the Wholesale Trade industry, mixed results are observed. Insufficient LIFO data are available for evaluations of the Agriculture, Forestry, and Fishing industry, the Mining industry, the Construction industry, and the Public Administration industry.

Keywords: FIFO Earnings; LIFO Earnings; Forecasting Operating Cash Flows; Incremental Predictive Content

\section{INTRODUCTION}

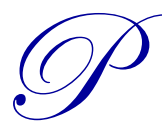

rior research into the ability of LIFO and FIFO earnings to forecast operating cash flows found that LIFO is superior to FIFO for this purpose. However, this previous research did not examine whether the results were industry specific, nor did it consider the effect of ex ante operating cash flows as a predictive variable (Murdoch, Dehning, and Krause, 2012).

Our research investigates whether the ability of earnings, measured under LIFO and FIFO, to forecast operating cash flows is affected by including ex ante measures of operating cash flows as an additional predictive variable and also investigates whether the predictive superiority of LIFO exists across all industries. We hope our results will provide additional evidence that the FASB can use to support its decision of whether to allow the continued use of LIFO or to discontinue LIFO's use for U.S. firms. 


\section{LITERATURE REVIEW}

There are currently two forces hastening the potential demise of the LIFO inventory method. First, there is the continuing world-wide convergence of U.S. and international accounting standards. International standards do not allow use of the LIFO inventory method and full convergence would remove LIFO from use by U.S. firms. Secondly, the elimination of LIFO could help ease the U.S. deficit (Carpenter, Boyle, and Ren, 2012) because its abolition might instantly create additional tax liabilities for all companies changing from LIFO (Hoffman \& McKenzie, 2009; Mock \& Simon, 2009).

There have been contrasting results in recent research regarding the ability of cash flows and earnings to predict future cash flows. Bandyopadhyay, Chen, Huang, and Jha (2010) argue that an increase in conservatism has coincided with an increased ability of earnings to predict future cash flows. Waldron and Jordan (2010) maintain, however, that the recent economic turbulence associated with the recession damaged accrual earnings' ability to forecast cash flows for certain industries. Murdoch and Krause (2012) also found that a decline in matching, likely related to the aforementioned increased conservatism, is associated with a decline in the ability of earnings to forecast operating cash flows.

\section{METHODOLOGY}

Cross-sectional data are used in this research. Three ex ante accounting variables are employed to predict ex-post operating cash flows. Each firm's dollar amount of total assets is used as an independent variable to control for firm size. Although it is common for researchers to control for firm size by deflating all variables by total assets or common equity, Kronmal (1993) cautions that such a practice can induce spurious correlation among the dependent and independent variables and recommends that a size metric be included as a separate independent variable.

Of course, there are different levels of income provided by firms in their income statements. When using earnings to forecast operating cash flows, it is important to construct an earnings variable so that it corresponds most closely to the operating cash flow metric it is meant to forecast. Cash flows related to gains and losses are not included in operating cash flows, so gains and losses should also be excluded from the earnings predictive variable. Nor do depreciation and amortization affect operating cash flows so the earnings metric employed should be before the deduction of depreciation and amortization expense. And because generally accepted accounting principles require all income taxes payments to be included among operating cash flows, it is important to subtract income tax expense from the earnings variable used as well. Therefore, we utilize operating income, before depreciation and amortization expense, less income tax expense as our earnings predictive variable (i.e., after-tax operating income).

Ex ante measures of operating cash flows and earnings are the second and third independent variables, respectively, in forecasting ex post operating cash flows. We compare whether there is a difference in the incremental predictive power of our earnings variable, derived under the LIFO and the FIFO inventory methods, in forecasting operating cash flows. The issue is whether the LIFO earnings variable provides predictive information content that is not contained in operating cash flows. However, instances in which LIFO earnings is a significant independent variable do not provide evidence that LIFO is superior to FIFO earnings in forecasting operating cash flows. To convince the FASB that LIFO should be preserved as an acceptable method, it probably must show that it is clearly superior to FIFO earnings in its predictive power.

Moreover, it is likely that for some industries, there may be differences in LIFO's and FIFO's predictive abilities that vary by the forecast horizon. When, for a specific industry, one of these inventory methods is consistently superior over all three forecast horizons, the evidence for LIFO's retention or elimination is strongest. For industries in which the forecast ability varies over the three forecast horizons, the evidence relating to the LIFO decision is weaker. And, of course, if FIFO's forecast ability is consistently stronger over the three-year forecast horizon, support for eliminating LIFO is strongest.

Regressions for predicting future operating cash flows, using the aforementioned accounting measures as predictive variables, are: 


$$
\begin{aligned}
& \mathrm{CFO}_{\mathrm{t}}=\mathrm{a}+\mathrm{b}_{1}\left(\mathrm{TA}_{\mathrm{t}-i}\right)+\mathrm{b}_{2}\left(\mathrm{CFO}_{\mathrm{t}-i}\right) \\
& \mathrm{CFO}_{\mathrm{t}}=\mathrm{a}+\mathrm{b}_{1}\left(\mathrm{TA}_{\mathrm{t}-i}\right)+\mathrm{b}_{2}\left(\mathrm{CFO}_{\mathrm{t}-i}\right)+\mathrm{b}_{3}\left(\mathrm{ATOI}_{\mathrm{LIFO}} \mathrm{t}_{\mathrm{t}-\mathrm{i}}\right) \\
& \mathrm{CFO}_{\mathrm{t}}=\mathrm{a}+\mathrm{b}_{1}\left(\mathrm{TA}_{\mathrm{t}-i}\right)+\mathrm{b}_{2}\left(\mathrm{CFO}_{\mathrm{t}-i}\right) \\
& \mathrm{CFO}_{\mathrm{t}}=\mathrm{a}+\mathrm{b}_{1}\left(\mathrm{TA}_{\mathrm{t}-i}\right)+\mathrm{b}_{2}\left(\mathrm{CFO}_{\mathrm{t}-i}\right)+\mathrm{b}_{3}\left(\mathrm{ATOI}_{\mathrm{FIFO}}, \mathrm{t}-\mathrm{i}\right)
\end{aligned}
$$

where: $\quad \mathrm{CFO}_{\mathrm{t}}=$ net cash provided (or used) by operating activities (Compustat data item no. 308)

$\mathrm{TA}_{\mathrm{t}-\mathrm{i}} \quad=\quad$ total assets (data item no. 6)

$\mathrm{CFO}_{\mathrm{t}-i}=$ net cash provided (or used) by operating activities (Compustat data item no. 308)

$\mathrm{ATOI}_{\mathrm{LIFO}}, \mathrm{t}-\mathrm{i}=$ operating income before depreciation and amortization (data item 13) less income tax expense (data item no. 16) for LIFO firms (i.e., after-tax operating income)

$\mathrm{ATOI}_{\mathrm{FIFO}}, \mathrm{t}-\mathrm{i}=$ operating income before depreciation and amortization (data item 13) less income tax expense (data item no. 16) for FIFO firms (i.e., after-tax operating income)

$t \quad=\quad$ year Compustat data item is measured

$i=1,2$, or 3 (i.e., the number of years the independent variables are lagged relative to $\mathrm{CFO}_{\mathrm{t}}$ )

Regression 1a is used to make one-, two-, and three-year ahead forecasts of operating cash flows for LIFO firms. Regression $1 \mathrm{~b}$ makes these same forecasts with the additional independent variable, $\mathrm{ATOI}_{\mathrm{LIFO}}{ }_{\mathrm{t}-\mathrm{i}}$. Regression $2 \mathrm{a}$ is identical to regression 1a, except the data used are from FIFO firms. Regression $2 b$ adds the FIFO earnings independent variable $\left(\mathrm{ATOI}_{\mathrm{FIFO}}, \mathrm{t}-\mathrm{i}\right.$ ) to variables used in $2 \mathrm{a}$ to evaluate whether it adds incremental predictive information content to that already possessed by ex ante total assets and ex ante operating cash flows. Simply put, the "1" represents the LIFO sample. The "2" represents the FIFO sample. The "a" indicates a regression that includes ex ante total assets and ex ante operating cash flows as independent, predictive variables. The "b" indicates a regression that adds ex ante LIFO or FIFO earnings as an additional independent, predictive variable.

\section{SAMPLE SELECTION}

The sample for this research is drawn from the database of Compustat firms from the years 1987-2010 (Standard and Poor's Compustat, 2011). Our investigation is based on the ability of ex ante operating cash flows, in conjunction with ex ante LIFO and FIFO earnings, to forecast ex post operating cash flows. Consequently, only firms that use the LIFO or the FIFO inventory method exclusively are potential sample firms. Sample firms must have available all Computstat variables necessitated by the cross-sectional research methodology. That is, we employ a "survivorship" sample.

Firms with uninterrupted data for all 24 years (1987-2010) will have 23 cross-sectional paired observations for use in making one-year ahead forecasts of operating cash flows. Each one year lag reduces each set of dependent and independent variables by one. Consequently, such a firm will have 22 cross-sectional observations for two-year ahead forecasts and 21 cross-sectional observations for three-year ahead forecasts. Of course, not all firms have 24 years of uninterrupted data available. Companies that began operations later than 1987 or ceased operations prior to 2010 will have fewer years of data available and fewer observations for use in these one-, two-, and three-year ahead forecasts.

Initially, we analyze whether all industries provide sufficient data upon which to draw conclusions. Table 1 displays the number of observations and percentage of total observations that each industry division has available for analyzing differences between the forecast ability of LIFO and FIFO firms. Industry divisions are based on Standard Industrial Classification (SIC) codes. There are 10 of these industry divisions (hereafter industries), as shown below:

Division A: Agriculture, Forestry, and Fishing (SIC codes 0100-0990)

Division B: Mining (SIC codes 1000-1400)

Division C: Construction (SIC codes 1500-1731)

Division D: Manufacturing (SIC codes 2000-3990) 
Division E: Transportation, Communications, Electric, Gas, and Sanitary Services (SIC codes 4000-4991)

Division F: Wholesale Trade (SIC codes 5000-5190)

Division G: Retail Trade (SIC codes 5200-5990)

Division H: Finance, Insurance, and Real Estate (SIC codes 6000-6799)

Division I: Services (SIC codes 7000-8900)

Division J: Public Administration (SIC codes 9000-9997)

Clearly, the ability to investigate industry differences in predictive information content between LIFO and FIFO earnings is limited by the number of LIFO observations. Both in total and for each industry, the number of LIFO observations are far fewer than those available for FIFO. The overall proportion of LIFO observations available is about $8 \%$ of available FIFO data. In 4 of the 10 industries (the Agricultural, Forestry, \& Fishing industry, the Mining industry, the Construction industry, and the Public Administration industry), there are too few LIFO observations to draw conclusions by industry. Consequently, we do not analyze the predictive information content of accounting data for these four industries.

The other six industries (Manufacturing, Transportation, Communications, Electric, Gas, \& Sanitary Services (hereafter Transportation), Wholesale Trade, Retail Trade, Finance, Insurance, \& Real Estate (hereafter Finance) and Services), combined, contain an average of $99.2 \%$ of all LIFO, and $97.0 \%$ of all FIFO, observations across the three forecast horizons.

Table 1: Number and Percentage of LIFO \& FIFO Observations By Industry \& Forecast Horizon

\begin{tabular}{|c|c|c|c|c|c|c|c|c|c|c|c|}
\hline 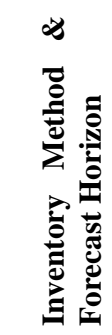 & 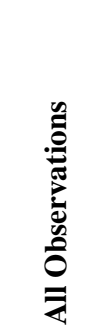 & 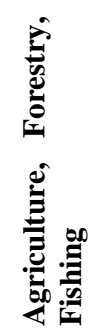 & 葛 & 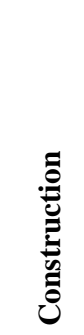 & 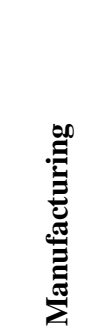 & 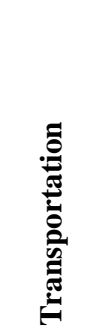 & 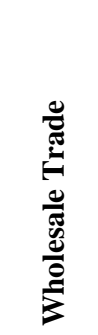 & 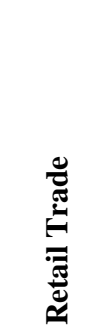 & $\begin{array}{l}\stackrel{\mathscr{E}}{\Xi} \\
\stackrel{\Xi}{\Xi}\end{array}$ & 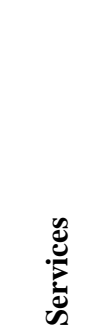 & 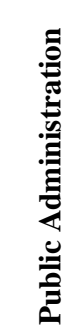 \\
\hline $\mathrm{LIFO}_{\mathrm{t}-1}$ & $\begin{array}{l}3,643 \\
100 \% \\
\end{array}$ & $\begin{array}{c}0 \\
0.0 \% \\
\end{array}$ & $\begin{array}{c}13 \\
0.4 \% \\
\end{array}$ & $\begin{array}{c}3 \\
0.1 \% \\
\end{array}$ & $\begin{array}{c}2,363 \\
64.9 \% \\
\end{array}$ & $\begin{array}{c}43 \\
1.2 \% \\
\end{array}$ & $\begin{array}{c}385 \\
10.6 \% \\
\end{array}$ & $\begin{array}{c}682 \\
18.7 \% \\
\end{array}$ & $\begin{array}{c}44 \\
1.2 \% \\
\end{array}$ & $\begin{array}{c}95 \\
2.6 \% \\
\end{array}$ & $\begin{array}{c}15 \\
0.4 \% \\
\end{array}$ \\
\hline $\mathrm{FIFO}_{\mathrm{t}-1}$ & $\begin{array}{c}45,351 \\
100 \%\end{array}$ & $\begin{array}{c}153 \\
0.3 \%\end{array}$ & $\begin{array}{c}430 \\
1.0 \%\end{array}$ & $\begin{array}{c}301 \\
0.7 \%\end{array}$ & $\begin{array}{l}28,785 \\
63.5 \%\end{array}$ & $\begin{array}{l}1,607 \\
3.5 \% \\
\end{array}$ & $\begin{array}{l}2,136 \\
4.7 \%\end{array}$ & $\begin{array}{l}3,608 \\
8.0 \%\end{array}$ & $\begin{array}{c}774 \\
1.7 \%\end{array}$ & $\begin{array}{l}7,015 \\
15.5 \%\end{array}$ & $\begin{array}{c}542 \\
1.2 \%\end{array}$ \\
\hline $\mathrm{LIFO}_{\mathrm{t}-2}$ & $\begin{array}{l}3,075 \\
100 \%\end{array}$ & $\begin{array}{c}0.07 \\
0.0 \%\end{array}$ & $\begin{array}{c}9 \\
0.3 \%\end{array}$ & $\begin{array}{c}2 \\
0.1 \%\end{array}$ & $\begin{array}{l}1,996 \\
64.9 \%\end{array}$ & $\begin{array}{c}33 \\
1.1 \%\end{array}$ & $\begin{array}{c}320 \\
10.4 \%\end{array}$ & $\begin{array}{c}585 \\
19.0 \% \\
\end{array}$ & $\begin{array}{c}37 \\
1.2 \% \\
\end{array}$ & $\begin{array}{c}81 \\
2.6 \% \\
\end{array}$ & $\begin{array}{c}12 \\
0.4 \% \\
\end{array}$ \\
\hline $\mathrm{FIFO}_{\mathrm{t}-2}$ & $\begin{array}{c}38,189 \\
100 \%\end{array}$ & $\begin{array}{c}132 \\
0.4 \%\end{array}$ & $\begin{array}{c}331 \\
0.9 \%\end{array}$ & $\begin{array}{c}237 \\
0.6 \%\end{array}$ & $\begin{array}{l}24,578 \\
64.4 \%\end{array}$ & $\begin{array}{l}1,294 \\
3.4 \%\end{array}$ & $\begin{array}{l}1,778 \\
4.7 \%\end{array}$ & $\begin{array}{l}3,037 \\
8.0 \%\end{array}$ & $\begin{array}{c}624 \\
1.6 \%\end{array}$ & $\begin{array}{l}5,747 \\
15.1 \%\end{array}$ & $\begin{array}{c}431 \\
1.1 \%\end{array}$ \\
\hline $\mathrm{LIFO}_{\mathrm{t}-3}$ & $\begin{array}{l}2,596 \\
100 \%\end{array}$ & $\begin{array}{c}0 \\
0.0 \%\end{array}$ & $\begin{array}{c}6 \\
0.2 \%\end{array}$ & $\begin{array}{c}1 \\
0.0 \%\end{array}$ & $\begin{array}{c}1,683 \\
64.8 \%\end{array}$ & $\begin{array}{c}24 \\
0.9 \%\end{array}$ & $\begin{array}{c}268 \\
10.3 \%\end{array}$ & $\begin{array}{c}507 \\
19.5 \%\end{array}$ & $\begin{array}{c}30 \\
1.2 \%\end{array}$ & $\begin{array}{c}68 \\
2.6 \%\end{array}$ & $\begin{array}{c}9 \\
0.4 \%\end{array}$ \\
\hline $\mathrm{FIFO}_{\mathrm{t}-3}$ & $\begin{array}{c}32,203 \\
100 \%\end{array}$ & $\begin{array}{c}114 \\
0.4 \%\end{array}$ & $\begin{array}{c}258 \\
0.8 \%\end{array}$ & $\begin{array}{c}187 \\
0.6 \%\end{array}$ & $\begin{array}{l}20,979 \\
65.2 \%\end{array}$ & $\begin{array}{l}1,038 \\
3.2 \%\end{array}$ & $\begin{array}{l}1,482 \\
4.6 \%\end{array}$ & $\begin{array}{l}2,562 \\
8.0 \%\end{array}$ & $\begin{array}{c}514 \\
1.6 \%\end{array}$ & $\begin{array}{l}4,724 \\
14.7 \%\end{array}$ & $\begin{array}{c}345 \\
1.1 \%\end{array}$ \\
\hline
\end{tabular}

\section{DESCRIPTIVE STATISTICS}

Table 2 displays the means for the dependent and each of the three independent variables, by industry, by inventory method, and by forecast horizon. Similarly, the mean for each inventory observation divided by each total asset observation, by industry and forecast horizon, is also displayed. Comparing LIFO with FIFO industry means reveals contrasts in size, proportion of assets held as inventory, and return on assets ( $\mathrm{ATOI}_{t-i}$ mean $\div \mathrm{TA}$ mean).

LIFO Manufacturing firms are an average of about 5 to 6 times larger, in terms of dollar asset cost, than are FIFO Manufacturing firms. Both LIFO and FIFO Manufacturing firms hold about $20 \%$ of their assets as inventory. LIFO Manufacturing firms earn about 11/2\% higher after-tax operating return on their assets (hereafter ROA). 
In contrast, LIFO Transportation industry firms are about half the size, or less, in terms of total assets, of FIFO firms in this industry. Both LIFO and FIFO firms also hold about the same proportion of their assets as inventory (5-6\%) and FIFO firms are about 5-6\% more profitable in ROA terms.

The average LIFO Wholesale Trade firm is more than twice the size of FIFO firms in this industry, but FIFO firms are about $2 \%$ more profitable in terms of ROA. LIFO firms hold about $25 \%$ more inventory, relative to the size of their assets, than do FIFO firms.

LIFO Retail Trade firms are about three and one-half times larger (in terms of total assets), hold about two and one-half times as much inventory, but are about $1 \%$ less profitable on their total assets than are FIFO firms.

FIFO Finance firms are an average of about 65-85 times larger than LIFO firms over the three-year forecast horizon, while carrying only about one-third as much inventory, relative to their total assets. FIFO firms are only slightly more profitable in terms of ROA.

Finally, LIFO Service organizations are an average of almost three times as large as FIFO Service firms and carry about the same proportion of inventory relative to their totals assets (7-8\%). FIFO Service firms have slightly higher ROA (about $1 \%$ ).

Table 2

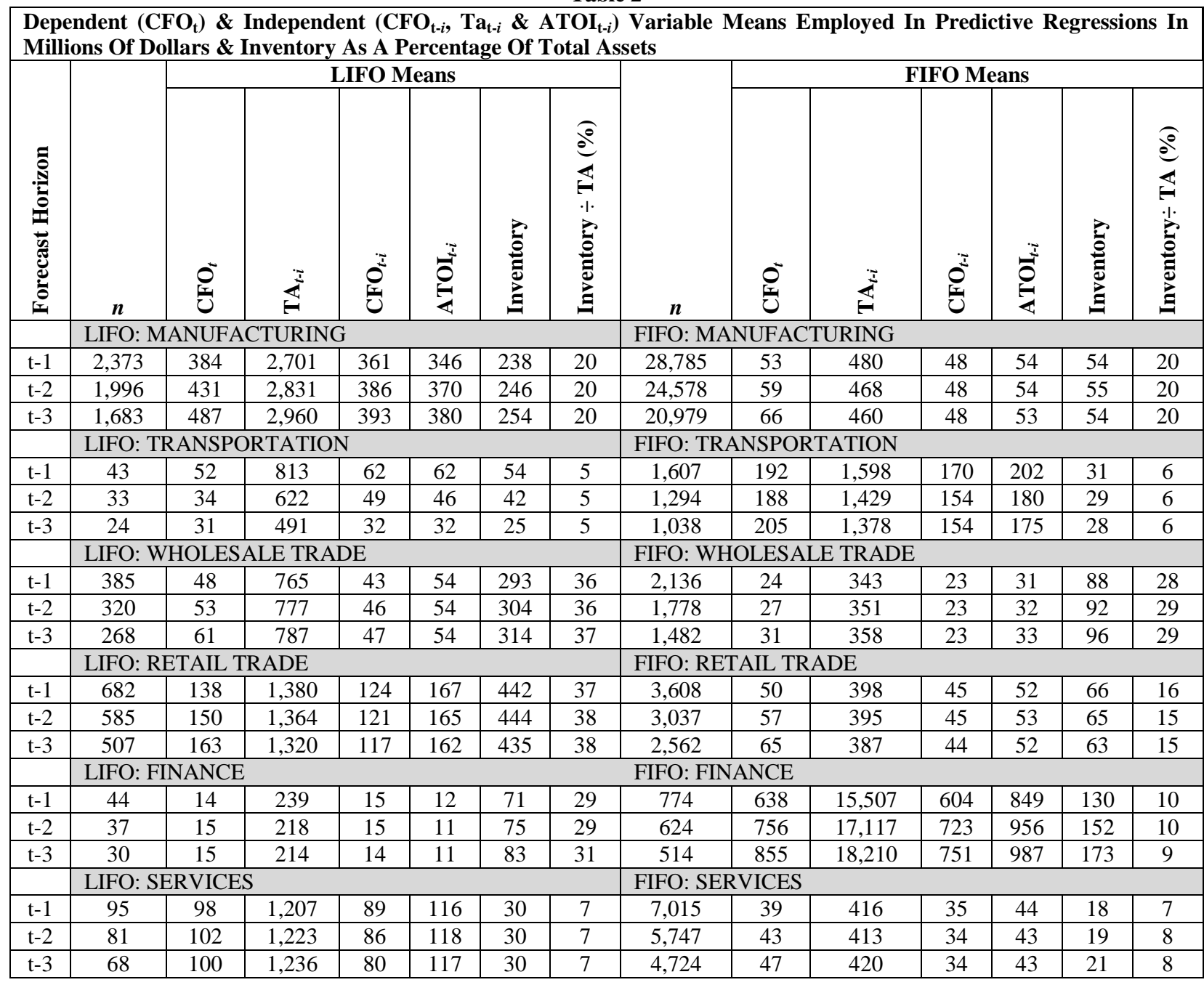


Generalizing, LIFO firms tend to be larger for four (Manufacturing, Wholesale Trade, Retail Trade, and Services) and smaller for two (Transportation and Finance) of the six industries. Finance firms using FIFO dwarf the size of LIFO firms in the industry. In three of the six industries (Manufacturing, Transportation, and Services), the proportion of inventory carried by both LIFO and FIFO firms, relative to total assets, is about the same. Although FIFO earnings, relative to assets, is higher than LIFO's income in all but the Manufacturing industry, these differences can be at least partially explained by the fact the LIFO profits, others things being equal, are lower due its transfer of more recent, typically higher, costs to cost of goods sold.

\section{RESULTS}

Table 3 displays, among the three independent variables, mean correlations across the three forecast horizons. Clearly, the independent variables, TA, CFO, and ATOI are highly correlated with one another. Over half these mean correlations exceed .90. Because larger (smaller) firms have greater (lesser) total asset costs and larger (lesser) operating cash flows, this result is not unexpected. Operating cash flows and earnings only differ by the effect of deferrals and accruals. "Multicollinearity is a frequent problem in economic and business data because of the high correlation with time among the different factors such as . . . sales, inventories, [and] profits, ...." (Makridakis and Wheelwright, 1978).

Table 3: Industry Mean Correlation Across Three Forecast Horizons

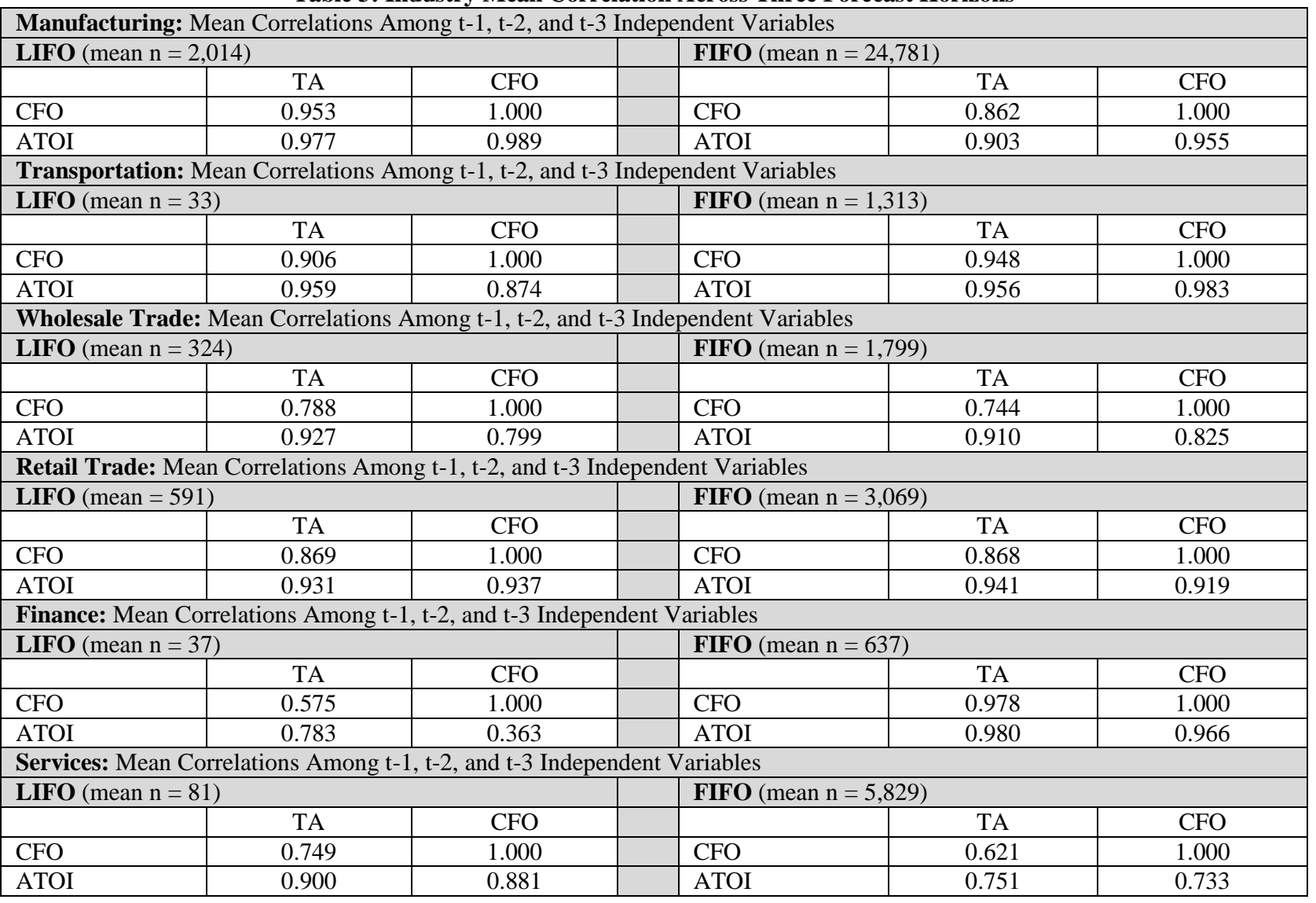

In situations with highly correlated independent variables, researchers often must deal with the effects of multicollinearity. Multicollinearity may cause coefficients of the independent variables to exhibit the sign opposite from expected and may be associated with low t-values. However, the multicollinearity may be causing these effects and may lead the researcher to an incorrect conclusion that one or more of the predictor variables is insignificant. Typically, large samples can mitigate the effects of multicollinearity and likely would for the FIFO firms' analyses. However, since there are far fewer LIFO than FIFO observations available in all industries, multicollinearity issues 
are much more probable for LIFO firms. Rather than relying on observed t-values to confirm the significance of adding $\mathrm{ATOI}_{\mathrm{LIFO}, t-i}$ or $\mathrm{ATOI}_{\mathrm{FIFO}, t-i}$ as independent variables, we observe whether adding them to each regression results in a significant reduction in the associated sums of squared errors (SSE). This test presents a clear signal regarding the significance of independent variables in a regression regardless of any multicollinearity issues (Fogler and Ganapathy, 1982).

\section{Significance of LIFO and FIFO Earnings}

Table 4 displays data from regressions forecasting $\mathrm{CFO}_{t}$ for each of the six industries analyzed. One-, two-, and three-year ahead forecasts are identified by the $\mathrm{t}-1, \mathrm{t}-2$, and $\mathrm{t}-3$ lags shown in the "Forecast Horizon" column. The six industry panels on the left display LIFO regression forecasted data. As discussed previously, each LIFO regression is identified by "1a" (with independent variables $\mathrm{TA}_{\mathrm{t}-i}$ and $\mathrm{CFO}_{\mathrm{t}-i}$ ) or " $1 \mathrm{~b}$ " (with $\mathrm{TA}_{\mathrm{t}-i}, \mathrm{CFO}_{\mathrm{t}-i}$ and $\left.\mathrm{ATOI}_{\mathrm{LIFO}}, \mathrm{t}-\mathrm{i}\right)$ in the Regression column to the right of the Forecast Horizon column. The six industry panels on the right present similar regression data for FIFO firms. Similarly, each FIFO regression is identified by "2a" (with independent variables $\mathrm{TA}_{\mathrm{t}-i}$ and $\mathrm{CFO}_{\mathrm{t}-i}$ ) or " $2 \mathrm{~b}$ " (with independent variables $\mathrm{TA}_{\mathrm{t}-i}, \mathrm{CFO}_{\mathrm{t}-i}$ and $\mathrm{ATOI}_{\mathrm{FIFO}}{ }_{\mathrm{t}-i}$ ) in the Regression column.

The number of cross-sectional observation sets $(n)$ for the dependent and independent variables is also presented. For example, there are 2,363 cross-sectional observations of $\mathrm{TA}_{t-1}, \mathrm{CFO}_{t-1}$, ATOI $\mathrm{LIFO}_{t-1}$ from LIFO Manufacturing firms and 28,785 cross-sectional observations of $\mathrm{TA}_{t-1}, \mathrm{CFO}_{t-1}, \mathrm{ATOI}_{\mathrm{FIFO}}$ t-1 from FIFO Manufacturing firms. For each regression, the associated $\mathrm{R}^{2}$ value and SSEs are also displayed. Of course, for all $1 \mathrm{~b}$ and $2 \mathrm{~b}$ regressions, the $\mathrm{R}^{2}$ values are greater and SSEs lesser than these same values are for the 1a and $2 \mathrm{a}$ regressions, since the former include the additional independent (earnings) variable. F-values and $p$-values relate to comparisons of the SSEs from the $1 \mathrm{a}$ and $1 \mathrm{~b}$, and from $2 \mathrm{a}$ and $2 \mathrm{~b}$ regressions for each forecast horizon and industry. The SSEs that differ significantly confirm that including ATOI $_{\mathrm{LIFO}, t-i}$ or $\mathrm{ATOI}_{\mathrm{FIFO}, t-i}$ as additional predictive variables significantly increase the proportion of $\mathrm{CFO}_{t}$ variation explained (i.e., $\mathrm{R}^{2}$ ).

In determining whether $\mathrm{ATOI}_{\mathrm{LIFO}, t-i}$ and $\mathrm{ATOI}_{\mathrm{FIFO}, t-i}$ are significant predictive variables for specific

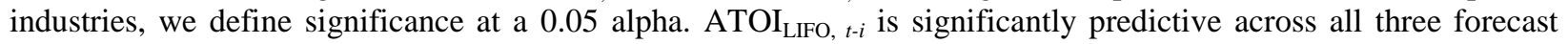
horizons for four industries (Manufacturing, Wholesale Trade, Retail Trade, and Services). For the Transportation industry, ATOI $\mathrm{LIFO}_{t-i}$ is a significant predictive variable for one- and two- year ahead forecasts only and for the Finance industry, ATOI $\mathrm{LIFO}_{t-i}$ is significant for only two-year ahead forecasts. It is expected that the predictive ability of earnings, whether it be LIFO or FIFO, will diminish as the forecast time horizon is extended.

ATOI $_{\mathrm{FIFO}, t-i}$ is significant across all three forecast horizons for four industries (Manufacturing, Wholesale Trade, Finance, and Services). For Transportation and Retail Trade firms, ATOI ${ }_{\mathrm{FIFO}, t-i}$ is significant for $\mathrm{t}-1$ and $\mathrm{t}-3$, but not for $\mathrm{t}-2$ regressions.

Table 5 displays multiple correlation coefficients from forecasts of operating cash flows, employing all three independent variables, across all three time horizons, and for all six industries. $Z$-values and $p$-values are from comparing tests of two correlations measured on independent groups of subjects (Cohen, Cohen, West, \& Aiken, 2003). Each of the six industries is represented vertically in a separate panel.

\section{Manufacturing Industry Results}

Results from analyzing Manufacturing firms clearly provide evidence for retaining the LIFO inventory method in this industry. In Table 4, we observed that both LIFO and FIFO earnings increase predictive power over total assets and operating cash flows. However, while FIFO earnings clearly aid in forecasting operating cash flows for FIFO firms across all three time horizons, LIFO earnings demonstrate a superior ability when forecasting operating cash flows for LIFO firms. Table 5 displays that Manufacturing forecasts that include LIFO earnings among predictive variables generate correlations of 0.966 for one-year ahead, 0.958 for two-year ahead, and 0.979 for three-year ahead forecasts. In comparison, the three forecasts that include FIFO earnings among the predictive variables produce correlations of $0.951,0.949$, and 0.950 for the one-, two-, and three-year forecasts of operating cash flows, respectively. All differences are extremely significant ( $p$-value <0.001). 


\section{Transportation, Communications, Electric, Gas, and Sanitary Services Industry Results}

Conclusions to be drawn for Transportation firms are less obvious. As observed in Table 4, for the Transportation industry, LIFO earnings enhance prediction for one- and two-year ahead, but not three-year ahead forecasts. FIFO earnings is significant for one- and three-year ahead forecasts, but not for two-year ahead forecasts. However, when comparing correlations related to LIFO and FIFO predictions (Table 5), FIFO earnings is superior for one- and two-year ahead forecasts, with there being no significant difference for three-year ahead forecasts. The lack of clarity for this industry may partially be due to LIFO having so few observations relative to FIFO. There is certainly no strong evidence for retaining LIFO in this industry.

Table 4: Significance of ATOI ti $_{t i}$ as an Independent Variable to Improve One-, Two, \& Three-Year Ahead Forecasts of CFO

\begin{tabular}{|c|c|c|c|c|c|c|c|c|c|c|c|c|}
\hline \multirow{2}{*}{ 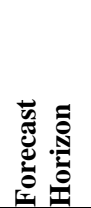 } & 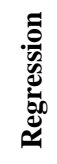 & $n$ & $\mathbf{R}^{2}$ & $\begin{array}{c}\text { SSE } \\
\text { (Millions) }\end{array}$ & $\mathbf{F}$ & $p$ & 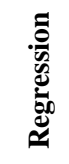 & $n$ & $\mathbf{R}^{2}$ & $\begin{array}{c}\text { SSE } \\
\text { (Millions) }\end{array}$ & $\mathbf{F}$ & $p$ \\
\hline & \multicolumn{6}{|c|}{ LIFO: Manufacturing } & \multicolumn{6}{|c|}{ FIFO: Manufacturing } \\
\hline \multirow{2}{*}{$\mathrm{t}-1$} & $1 \mathrm{a}$ & \multirow{2}{*}{2,363} & 0.931 & $1,381.759$ & \multirow{2}{*}{46.0} & \multirow{2}{*}{$<.001$} & $2 a$ & \multirow{2}{*}{28,785} & 0.899 & 533.615 & \multirow{2}{*}{1,890} & \multirow{2}{*}{$<.001$} \\
\hline & $1 \mathrm{~b}$ & & 0.933 & $1,355.315$ & & & $2 b$ & & 0.905 & 500.727 & & \\
\hline \multirow{2}{*}{$t-2$} & $1 \mathrm{a}$ & \multirow{2}{*}{1,996} & 0.915 & $1,695.238$ & \multirow{2}{*}{54.7} & \multirow{2}{*}{$<.001$} & $2 a$ & \multirow{2}{*}{24,578} & 0.899 & 515.395 & \multirow{2}{*}{234.6} & \multirow{2}{*}{$<.001$} \\
\hline & $1 \mathrm{~b}$ & & 0.917 & $1,649.943$ & & & $2 b$ & & 0.900 & 510.522 & & \\
\hline \multirow{3}{*}{$t-3$} & $1 \mathrm{a}$ & \multirow{2}{*}{1,683} & 0.903 & $1,925.418$ & \multirow{2}{*}{369.2} & \multirow{2}{*}{$<.001$} & $2 a$ & 0070 & 0.927 & 698.232 & 810 & 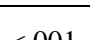 \\
\hline & $1 \mathrm{~b}$ & & 0.920 & $1,578.382$ & & & $2 b$ & 20,919 & 0.928 & 695.546 & 81.0 & $<.001$ \\
\hline & $\begin{array}{l}\text { LIF } \\
\text { and }\end{array}$ & $\begin{array}{l}\text { Tran } \\
\text { anitar }\end{array}$ & $\begin{array}{l}\text { ortation } \\
\text { ervices }\end{array}$ & Communicat & Is, Elec & ic, Gas, & $\begin{array}{l}\text { FIFC } \\
\text { Sani }\end{array}$ & $\begin{array}{l}\text { Transp } \\
\text { ry Servi }\end{array}$ & ation, $C$ & nmunicatio & Electric & as, and \\
\hline & $1 \mathrm{a}$ & 43 & 0.648 & 0.157 & & & $2 a$ & & 0.954 & 83.208 & & \\
\hline $\mathrm{t}-\mathrm{l}$ & $1 \mathrm{~b}$ & 43 & 0.705 & 0.132 & 7.6 & .009 & $2 b$ & 1,607 & 0.958 & 75.688 & 159.3 & $<.001$ \\
\hline & $1 \mathrm{a}$ & & 0.380 & 0.110 & & & $2 a$ & & 0.868 & 151.646 & & \\
\hline$t-2$ & $1 \mathrm{~b}$ & 33 & 0.600 & 0.071 & 16.0 & $<.001$ & $2 b$ & 1,294 & 0.868 & 151.640 & 0.0 & 0.932 \\
\hline+3 & $1 \mathrm{a}$ & 24 & 0.685 & 0.042 & 0 & 0.074 & $2 a$ & 1038 & 0.880 & 220.301 & & $<001$ \\
\hline $\mathrm{t}-3$ & $1 \mathrm{~b}$ & 24 & 0.685 & 0.042 & 0.0 & 0.974 & $2 b$ & 1,038 & 0.881 & 217.835 & 11.7 & $<.001$ \\
\hline & LIF & Who & ale Tra & & & & FIFC & Wholes & Trade & & & \\
\hline & $1 \mathrm{a}$ & & 0.743 & 2.341 & & & $2 a$ & & 0.667 & 10.380 & & \\
\hline $\mathrm{t}-1$ & $1 \mathrm{~b}$ & 385 & 0.746 & 2.311 & 4.8 & 0.029 & $2 b$ & 2,136 & 0.778 & 6.922 & 1,063 & $<.001$ \\
\hline t? & $1 \mathrm{a}$ & 200 & 0.754 & 2.199 & 260 & 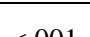 & $2 a$ & 1778 & 0.652 & 10.675 & 2050 & $<001$ \\
\hline$t-2$ & $1 \mathrm{~b}$ & 320 & 0.773 & 2.032 & 26.0 & $<.001$ & $2 b$ & $1,7 / 8$ & 0.715 & 8.732 & 395.0 & $<.001$ \\
\hline+3 & $1 \mathrm{a}$ & 268 & 0.875 & 2.049 & 200 & $<001$ & $2 a$ & 1482 & 0.772 & 12.174 & 2304 & $<0 \cap 1$ \\
\hline $\mathrm{t}-3$ & $1 \mathrm{~b}$ & 268 & 0.885 & 1.905 & 20.0 & $<.001$ & $2 b$ & 1,482 & 0.819 & 9.950 & 330.4 & $<.001$ \\
\hline & LIF & : Reta & rade & & & & FIFC & Retail T & & & & \\
\hline & $1 \mathrm{a}$ & & 0.877 & 11.811 & 874 & $<001$ & $2 a$ & 2600 & 0.920 & 19.326 & 1260 & 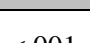 \\
\hline$t-1$ & $1 \mathrm{~b}$ & 682 & 0.891 & 10.463 & 87.4 & $<.001$ & $2 b$ & 3,608 & 0.923 & 18.673 & 126.0 & $<.001$ \\
\hline & $1 \mathrm{a}$ & & 0.859 & 13.053 & & & $2 a$ & & 0.885 & 27.328 & & \\
\hline $\mathrm{t}-2$ & $1 \mathrm{~b}$ & 585 & 0.864 & 12.607 & 20.6 & $<.001$ & $2 b$ & 3,037 & .0885 & 27.328 & 0.0 & 0.932 \\
\hline$t-3$ & $1 \mathrm{a}$ & 507 & 0.796 & 18.502 & & & $2 a$ & & 0.921 & 34.827 & & \\
\hline$t-3$ & $1 \mathrm{~b}$ & 507 & 0.800 & 18.199 & 8.4 & 0.004 & $2 b$ & 2,562 & 0.922 & 34.672 & 11.4 & $<.001$ \\
\hline & LIF & : Fina & Insur: & ce, and Real & tate & & FIFC & Finance & nsuranc & and Real Est & & \\
\hline & $1 \mathrm{a}$ & 14 & 0.513 & 0.012 & & 0055 & $2 a$ & 774 & 0.891 & $1,113.071$ & & \\
\hline $\mathrm{t}-\mathrm{l}$ & $1 \mathrm{~b}$ & 44 & 0.557 & 0.011 & 3.9 & 0.055 & $2 b$ & 774 & 0.894 & $1,102.697$ & 21.2 & $<.001$ \\
\hline & $1 \mathrm{a}$ & 37 & 0.553 & 0.010 & & & $2 a$ & & 0.885 & $1,165.025$ & & \\
\hline$t-2$ & $1 \mathrm{~b}$ & 37 & 0.650 & 0.008 & 9.2 & 0.005 & $2 \mathrm{~b}$ & 624 & 0.898 & $1,032.142$ & 79.8 & $<.001$ \\
\hline & 1a & 20 & 0.599 & 0.006 & & ค ค०० & $2 a$ & 511 & 0.936 & $1,193.892$ & 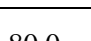 & \\
\hline$t-3$ & $1 \mathrm{~b}$ & 30 & 0.617 & 0.006 & 1.2 & 0.283 & $2 b$ & 514 & 0.945 & $1,032.079$ & 80.0 & $<.001$ \\
\hline & LIF & :Serv & & & & & LIFC & Service & & & & \\
\hline & $1 \mathrm{a}$ & & 0.861 & 0.330 & & & $2 a$ & & 0.791 & 68.489 & & \\
\hline $\mathrm{t}-1$ & $1 \mathrm{~b}$ & 95 & 0.885 & 0.273 & 19.1 & $<.001$ & $2 \mathrm{~b}$ & 7,015 & 0.793 & 68.105 & 39.5 & $<.001$ \\
\hline & $1 \mathrm{a}$ & & 0.797 & 0.429 & & & $2 a$ & & 0.626 & 72.526 & & \\
\hline$t-2$ & $1 \mathrm{~b}$ & 81 & 0.829 & 0.360 & 14.6 & $<.001$ & $2 b$ & 5,757 & 0.636 & 70.609 & 155.9 & $<.001$ \\
\hline & $1 \mathrm{a}$ & & 0.877 & 0.366 & & & $2 a$ & & 0.691 & 93.275 & & \\
\hline$t-3$ & $1 \mathrm{~b}$ & 68 & 0.903 & 0.291 & 16.3 & $<.001$ & $2 b$ & 4,724 & 0.695 & 92.333 & 48.1 & $<.001$ \\
\hline
\end{tabular}


Table 5: Comparing the Predictive Information Content of LIFO \& FIFO After-tax Operating Income

\begin{tabular}{|c|c|c|c|c|c|c|c|c|c|}
\hline & \multicolumn{3}{|c|}{$t-1$} & \multicolumn{3}{|c|}{$t-2$} & \multicolumn{3}{|c|}{$t-3$} \\
\hline Regression & $\mathbf{r}$ & $Z$ & $p$-value & $\mathbf{r}$ & $Z$ & $p$-value & $\mathbf{r}$ & $Z$ & $p$-value \\
\hline \multicolumn{10}{|l|}{ Manufacturing } \\
\hline $1 \mathrm{~b}$ (with $\mathrm{ATOI}_{\mathrm{LIFO}, t-i}$ ) & 0.966 & \multirow{2}{*}{8.37} & \multirow{2}{*}{$<.001$} & 0.958 & \multirow{2}{*}{4.34} & \multirow{2}{*}{$<.001$} & 0.979 & \multirow{2}{*}{11.59} & \multirow{2}{*}{$<.001$} \\
\hline $2 \mathrm{~b}$ (with ATOI $\left.{ }_{\mathrm{FIFO}, t-i}\right)$ & 0.951 & & & 0.949 & & & 0.963 & & \\
\hline \multicolumn{10}{|c|}{ Transportation, Communications, Electric, Gas, and Sanitary Services } \\
\hline $1 \mathrm{~b}\left(\right.$ with $\left.\mathrm{ATOI}_{\mathrm{LIFO}, t-i}\right)$ & 0.840 & \multirow{2}{*}{6.57} & \multirow{2}{*}{$<.001$} & 0.775 & \multirow{2}{*}{3.45} & \multirow{2}{*}{$<.001$} & 0.910 & \multirow{2}{*}{0.910} & \multirow{2}{*}{.362} \\
\hline $2 \mathrm{~b}\left(\right.$ with $\left.\mathrm{ATOI}_{\mathrm{FIFO}, t-i}\right)$ & 0.979 & & & 0.931 & & & 0.939 & & \\
\hline \multicolumn{10}{|l|}{ Wholesale Trade } \\
\hline $1 \mathrm{~b}\left(\right.$ with $\left.\mathrm{ATOI}_{\mathrm{LIFO}, t-i}\right)$ & 0.864 & \multirow{2}{*}{1.36} & \multirow{2}{*}{0.173} & 0.879 & \multirow{2}{*}{2.14} & \multirow{2}{*}{0.032} & 0.941 & \multirow{2}{*}{3.67} & \multirow{2}{*}{$<.001$} \\
\hline $2 \mathrm{~b}($ with $\mathrm{ATOI}$ FIFO, $t-i)$ & 0.882 & & & 0.846 & & & 0.905 & & \\
\hline \multicolumn{10}{|l|}{ Retail Trade } \\
\hline $1 \mathrm{~b}$ (with $\mathrm{ATOI}_{\mathrm{LIFO}, t-i}$ ) & 0.944 & \multirow{2}{*}{4.27} & \multirow{2}{*}{$<.001$} & 0.929 & \multirow{2}{*}{1.97} & \multirow{2}{*}{0.049} & 0.946 & \multirow{2}{*}{3.25} & \multirow{2}{*}{$<.001$} \\
\hline $2 \mathrm{~b}\left(\right.$ with $\left.\mathrm{ATOI}_{\mathrm{FIFO}, t-i}\right)$ & 0.961 & & & 0.941 & & & 0.960 & & \\
\hline \multicolumn{10}{|c|}{ Finance, Insurance, and Real Estate } \\
\hline $1 \mathrm{~b}$ (with $\left.\mathrm{ATOI}_{\mathrm{LIFO}, t-i}\right)$ & 0.746 & \multirow{2}{*}{5.14} & \multirow{2}{*}{$<.001$} & 0.806 & & & 0.785 & & \\
\hline $2 \mathrm{~b}$ (with ATOI $\mathrm{FIFO}, t-i)$ & 0.946 & & & 0.948 & 3.94 & $<.001$ & 0.972 & 5.42 & $<.001$ \\
\hline Services & & & & & & & & & \\
\hline $1 \mathrm{~b}\left(\right.$ with $\left.\mathrm{ATOI}_{\mathrm{LIFO}, t-i}\right)$ & 0.941 & 308 & 0002 & 0.911 & 386 & $<001$ & 0.950 & 5.09 & $<001$ \\
\hline $2 \mathrm{~b}$ (with $\left.\mathrm{ATOI}_{\mathrm{FIFO}, t-i}\right)$ & 0.890 & 5.08 & 0.002 & 0.797 & 5.80 & .001 & 0.834 & 5.09 & .001 \\
\hline
\end{tabular}

\section{Wholesale Trade Industry Results}

Similar to the Transportation industry, the Wholesale Trade industry lacks a clear distinction between incremental predictive information content of LIFO and FIFO earnings. We observe in Table 5, that while FIFO has the higher correlation with one-year ahead forecasts of CFO (.882), it is not significantly better than LIFO's predictions (.864). However, LIFO produces significantly better forecasts than FIFO for two- and three-year ahead forecasts. It is noteworthy that some of LIFO's superiority may be due to the fact that LIFO's inventory, relative to its total assets, is larger than for FIFO (Table 2). It is logical that inventory that comprises a larger proportion of firms' total assets may be more important as a predictive variable. Nonetheless, given that LIFO earnings is the better predictor only for two- and three-year ahead forecasts, the evidence to support LIFO's retention for the Wholesale Trade industry is not particularly strong.

\section{Retail Trade Industry Results}

From Table 4, we see that LIFO earnings in the Retail industry provides incremental predictive information content for forecasts of operating cash flows across all three time horizons. FIFO earnings provides incremental predictive content for one- and three-year ahead, but not for two-year ahead, forecasts. When matched against LIFO earnings (Table 5), FIFO earnings generates correlations of .961, .941, and .960 across the one-, two-, and threeyear ahead forecasts, respectively, compared to LIFO's .944, .929, and .946. All three differences by which FIFO correlations exceed LIFO's are significant at alphas of at least .05. FIFO's superiority is in spite of the fact that LIFO firms' inventories average more than twice as much, relative to total assets, as do FIFO firms' inventories (Table 2). These results provide no evidence to support LIFO's retention for the Retail Trade industry.

\section{Finance, Insurance, and Real Estate Industry Results}

As observed in Table 4, FIFO Finance industry earnings demonstrate incremental predictive content across all three time horizons while LIFO demonstrates incremental predictive content only for two-year ahead forecasts. Comparisons of FIFO earnings' multiple correlation coefficients (in Table 5) are .946, .948, and .972 for one-, two-, and three-year ahead forecasts, respectively, compared to .746, .806, and .785 for LIFO earnings. The differences in favor of FIFO earnings are all significant at <.001 $p$-values. This is despite the fact that LIFO inventory, as a proportion of total assets, is about three times as large as the same proportion for FIFO firms (Table 2). These results provide no support for LIFO's retention for use in the Finance, Insurance, and Real Estate industry. 


\section{Services Industry Results}

We observe (in Table 4) that for the Services industry, similar to results for the Manufacturing industry, both LIFO and FIFO earnings possess incremental predictive content across all three forecast horizons. Additionally, including earnings for LIFO firms in the predictive model generates better forecasts than including earnings for FIFO firms does (in Table 5). The predictive model that includes earnings for LIFO firms generates correlations of $.941, .911$, and .950 for forecasts of one-, two-, and three-year ahead operating cash flows, respectively. The model containing FIFO earnings produces smaller correlations $(.890, .797$, and .834) across the three forecast horizons. All three differences are significant at $p$-values of at least .001. Similar to results for Manufacturing industry firms, strong evidence is provided for retaining LIFO's use for Service industry firms.

\section{SUMMARY}

The use of the LIFO inventory method by U.S. firms is in danger of being eliminated because it does not conform to International Accounting Standards. However, the FASB (2010) has argued that accounting data should provide investors and creditors with the ability to assess future cash flows to the enterprise.

First, this research investigates the incremental predictive information content of LIFO and FIFO earnings, beyond that provided by ex ante measures of total assets and operating cash flows, to forecast ex post operating cash flows. Secondly, the incremental predictive information content of these earnings is examined by industry. Accordingly, it extends prior research in the area of the consequences of eliminating the LIFO method for U.S. firms.

We find that the incremental predictive information content of these inventory methods varies by industry. LIFO provides significant incremental predictive power across all three time horizons for firms in the Manufacturing, Wholesale Trade, Retail Trade, and Services industries. For Manufacturing and Service industry firms, LIFO explains significantly more variation in future operating cash flows than does FIFO earnings for firms using FIFO. However, FIFO explains more variation in FIFO firms' future operating cash flows than does LIFO earnings for LIFO Retail Trade firms.

For the other three industry groups examined (Transportation, Wholesale Trade, and Retail Trade), LIFO and FIFO firms were inconsistent with respect to either being able to provide incremental predictive power or to dominate the other inventory method in comparisons across all three time horizons.

Insufficient data upon which to draw conclusions would not permit analyses of the predictive information content of LIFO earnings for the Agriculture, Forestry, and Fishing, the Mining, the Construction, or the Public Administration industries. That is, too few firms in these industries use LIFO for an analysis of LIFO earnings' ability to enhance forecasts of operating cash flow or to compare such ability to that of FIFO earnings for FIFO firms.

Prior research has shown that the LIFO inventory method produces an earnings metric that is superior to FIFO earnings for the purpose of forecasting operating cash flows (Murdoch, Dehning, and Krause, 2012), yet this earlier research is not industry specific. In this earlier research, it is likely that the exceptionally strong predictive superiority of LIFO earnings for Manufacturing and Service industry firms overwhelmed the weaker superiority of FIFO earnings for other industries.

\section{AUTHOR INFORMATION}

Brock Murdoch has been recognized by the California State University, Chico College of Business for teaching and research excellence. Dr. Murdoch has authored numerous articles, including publications in The Accounting Review, Financial Analysts Journal, Journal of Accounting, Auditing and Finance, The Journal of Applied Business Research, and several other peer-reviewed periodicals. E-mail: bmurdoch@csuchico.edu (Corresponding author) 
Bruce Dehning was awarded the Wang-Fradkin Professorship at Chapman University in 2004 and named a Fulbright Scholar to teach in the Czech Republic in 2005. He has published articles in MIS Quarterly, Journal of Management Information Systems, Journal of Operations Management, Journal of Information Systems, Journal of Strategic Information Systems, International Journal of Accounting Information Systems, Information and Management, and other academic journals. His work has been cited more than 1,200 times. In 2006 he received the Notable Contributions to the Literature Award from the American Accounting Association Information Systems Section for a paper he co-authored with Vernon J. Richardson. E-mail: bdehning@chapman.edu

Paul Krause has taught for over 40 years, including visiting professorships in Australia and New Zealand. Dr. Krause's publications have appeared in the Journal of Accounting Education, Accounting and Business Research, Journal of Business and Economic Perspectives, Accountants' Journal, and The Journal of Applied Business Research. E-mail: paul@paulkrause.com

\section{REFERENCES}

1. Bandyopadhyay, S. P., Chen, C., Huang, A. G., \& Jha R. (2010). Accounting conservatism and the temporal trends in current earnings' ability to predict future cash flows versus future earnings: Evidence on the trade-off between relevance and reliability. Contemporary Accounting Research, 27 (2), 413-460.

2. Carpenter, B.W., Boyle, D. M., \& Ren, Y. (2012). The impending demise of LIFO: History, threats, implications, and potential remedies. The Journal of Applied Business Research, 28 (4), 645-650.

3. Cohen, J., Cohen, P., West, S. G., \& Aiken L. S. (2003). Applied multiple regression/correlation analysis for the behavioral sciences. Mahwah, NJ: Erlbaum.

4. Financial Accounting Standards Board (2010). Conceptual Framework for Financial Reporting — Chapter 1, The Objective of General Purpose Financial Reporting, and Chapter 3, Qualitative Characteristics of Useful Financial Information (a replacement of FASB Concepts Statements No. 1 and No. 2). Norwalk, CT. FASB

5. Fogler, H. R., \& Ganapathy, S. (1982). Financial econometrics for researchers in finance and accounting. Englewood Cliffs, NJ: Prentice-Hall, Inc.

6. Hoffman, M.J.R. \& McKenzie, K. S. (2009). Must LIFO go to make way for IFRS? The Tax Adviser, March, 156-161.

7. Kronmal, R. A. (1993). Spurious correlation and the fallacy of the ratio standard revisited. Journal of the Royal Statistical Society: Series A, 156 (3), 379-392.

8. Makridakis, S., \& Wheelwright, S. C. (1978). Forecasting: Methods and applications. New York: John Wiley \& Sons.

9. Mock, R.P., \& Simon, A. (2009). The LIFO, IFRS conversion: An explosive concoction. Tax Analysts. Retrieved from: http://ssrn.com/abstract=1536815

10. Murdoch, B., \& Krause, P. (2012). The decline in matching and earnings' ability to forecast operating cash flows. Journal of Applied Business Research, 28 (4), 701-708.

11. Murdoch, B., Dehning, B., \& Krause, P. (2012). Earnings under generally accepted inventory methods and the prediction of operating cash flows. Journal of Business and Economic Perspectives, 39 (1), 61-72.

12. Standard and Poor's Compustat (2011). Compustat North America data files, 1990-2010. New York: Standard \& Poor's.

13. Waldron, M., \& Jordan, C. (2010). The comparative predictive abilities of accrual earnings and cash flows in periods of economic turbulence: The case of the IT bubble. Journal of Applied Business Research, 26 (1), 85-98. 


\section{$\underline{\text { NOTES }}$}

